\title{
HERMENEUTIKA AL-QUR`AN HASAN HANAFI DAN REFLEKSINYA DALAM AKSIOLOGIS-ETIS
}

\author{
Amril Mansur
}

\begin{abstract}
The hermeneutic of $a l-Q u r^{\prime} a n$ that is set forward by Hasan Hanafi seeks such as an interpretation of Qur'anic texts whose methodology which is oriented to liberate the life of people from despotism, cruelty, underdevelopment and stupidity become that of a justice, a liberty and a development. For Hasan Hanafi this hermeneutic is not only the interpretations technique that is methodical orientation to an objectively theorizing as being in theoretical hermeneutic or the philosophical interpretation as being in philosophical hermeneutic, but also, it is an instrument that serves on an interest activism critically and emancipatory for the current human life. The hermeneutic of al-Qur'an in which has three stages namely the historical critic, the eidetic and the activism, according to Hasan Hanafi can make meaning of the Qur'an's verses in function very well for disappearing despotism. Nevertheless, it also certainly opens to opportunity to reduce meaning of the ethical temporal rightness. For prohibiting to this such implications should have been needed to use dialectics in analyzing khair li zatihi and khair li ghairihi.
\end{abstract}

Key words: Texts, hermeneutics, and interpretation methodology

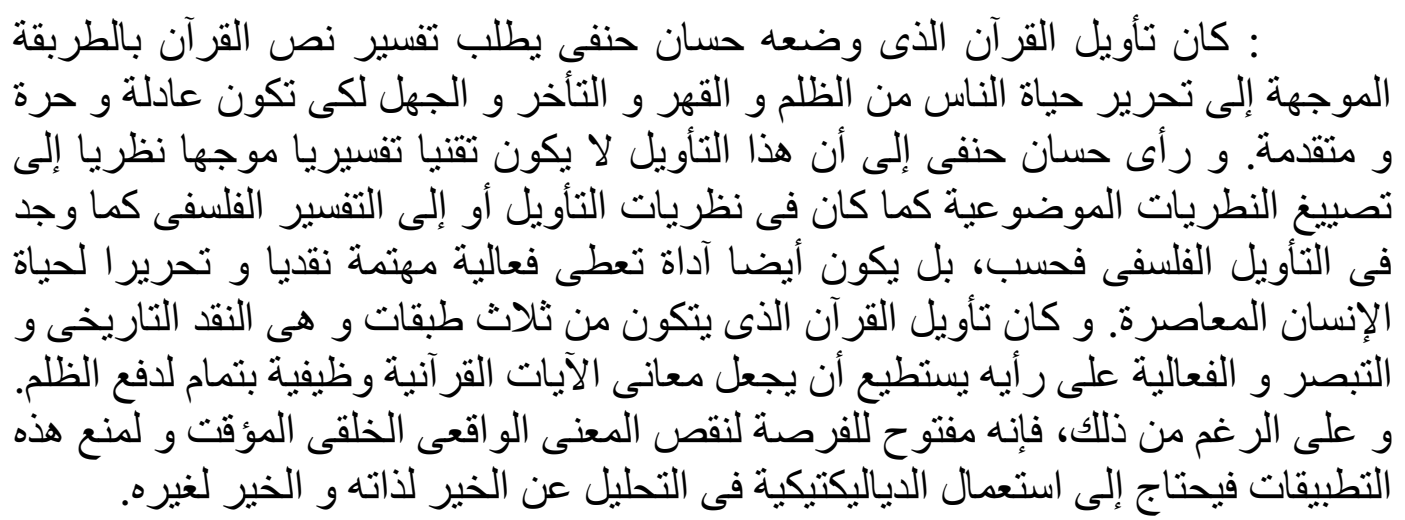

\section{Pendahuluan}

Upaya untuk memfungsikan pesan-pesan moral al-Qur`an dalam konteks kehidupan saat ini memang telah banyak menjadi keinginan dari para pemikir Islam kontemporer Hal ini boleh jadi di antaranya adanya indikasi yang menunjukkan bahwa pesan-pesan moral imperatif dan alternatif al-Qur'an kurang dapat diaplikasikan, sehingga menjadikan al-Qur`an kehilangan makna aplikatif-praktis dan historisnya dalam kehidupan yang semakin terkebelakang dan tertindas oleh strukturalisasi kehidupan yang diciptakan oleh kekuasaan dan ideologi tertentu. Pada hal pada satu sisi misi al-Qur`an yang sesungguhnya adalah melahirkan kehidupan yang berkeadilan terlepas dari segala macam penindasan, utamanya yang telah terstruktur dan terlembagakan.

Pertanyaan yang selalu mengelitik para pemikir kontemporer tafsir alQur`an biasanya berkisar tentang kenapa al-Qur`an dalam kehidupan yang 
serba menindas ini-struktural dan ideologis-politis dan otoriitas tertentu yang tidak menguntungkan seperti ini justru didiamkan dan kurangnya upaya mengintegrasikan pesan-pesan makna sosial al-Qur`an dalam kehidupan praksis senyatanya, pada hal sesungguhnya misi awal dan utama al-Qur'an adalah sangat anti pada penindasan, kemiskinan, keterbelakangan, sebaliknya sangat konsen pada keadilan, kesejahteraan dan kemajuan.

Keprihatinan atas praktek yang menjadikan makna-makna teks al-Qur`an tidak lagi berimplikasi positif dan etis bagi transformasi umat menuju kebebasannya dari segala macam penindasan, kezaliman, keterbelakangan, merupakan keprihatinan utama Hasan Hanafi sebagai seorang pemikir kontemporer Islam saat ini.

Hasan Hanafi seperti para pemikir kontemporer lainnya mencoba memberikan tawaran konstruk metodologis bagi penafsiran al-Qur`an, agar makna teks al-Qur'an dapat memberikan transformasi bagi kehidupan umat Muslim khususnya dan kebaikan manusia umumnya. Makalah ini mencoba membedah model konstruk metodologis penafsiran al-Qur`an yang ditawarkan oleh Hasan Hanafi yang akhir-akhir ini dilebeli dengan Hermeneutika Pembebasan,i serta melakukan telaah refleksis-konsekuensis dari sisi aksiologisetis dalam wacana epistemik dan produk pemikirannya.

Dimaksudkan telaah yang terakhir ini adalah semacam telaahan yang dikembangkan sedemikian rupa baik dari aspek metodologis pemikirannya maupun produk yang dihasilkannya yang secara niscaya memunculkan semacam kegamangan dan kekhawatiran sebagai konsekuensi logis dari model pemikiran Hasan Hanafi ini dalam konteks kebenaran nilai etis.

\section{Hermeneutika Al-aqur`an Hasan Hanafi: Sebuah Tafsir Sosial}

Tafsir al-Qur`an yang bernuansa sosial merupakan perhatian utama yang dilakukan Hasan Hanafi melalui hermeneutikanya. Konsennya terhadap tafsir seperti ini lantaran menurutnya beberapa tafsir ala hermeneutika yang dilakukan oleh para pemikir Islam kontemporer semisal Fazlur Rahman, Muhammed Arkoen dan Muhammad Sahrur, ii dan masih banyak yang lainya lebih berupaya pada pencarian makna objektif-teoritis dari teks-teks al-Qur`an dari pada makna emansipatoris-praktis, sehingga akibatnya problema kemanusiaan seperti kemiskinan, penindasan dan ketidakadilan, cenderung terabaikan. Pada hal sesungguhnya realitas sosial umat seperti inilah yang semestinya segera mendapat jawaban guna melepaskan umat Muslim dari penindasan dan keterbelakangan yang telah merajalela dalam kehidupan.iii

Pada prinsipnya model penafsiran yang ditawarkannya seperti disebutkan di atas tidak terlepas dari sentuhan model kerja metodologis semisal hermeneutika, fenomenologi dan marxisme setelah terlebih dahulu mensintesiskannya dengan ilmu-ilmu keislaman klasik iv

Pemanfaatan tiga piranti metodologis keilmuan ini dalam pemikiran Hasan Hanafi terindikasi kuat dari ungkapannya yang sangat tegas bahwa yang perlu ditanyakan sebagai ujian dari suatu penafsiran adalah sejauhmana keterkaitan makna yang dihasilkan dari suatu penafsiran bagi emansipasi dan perubahan 
kemanusiaan. Melalui tiga piranti metodologis tersebut sangat dimungkinkan ditempat-kannya keterpurukan umat sebagai realitas sosial yang dapat berbicara akan dirinya sebagai human construction yang penuh kontradiksi dan perbedaan-perbedaan yang bukannya dapat diterima begitu saja secara pasrah.

Umat sebagai realitas sosial di mata hermeneutika filosofis utamanya sangat terkait dengan cara mengada manusia dan cara manusia memahami kenyataannya, sedemikian rupa dalam konteks seperti ini hermeneutika ini disebut pula dengan fenomenologis oleh Marthin Heidegger.v Sedangkan Marxisme yang lebih mengorientasi-kan perubahan atas perjuangan kelas tertindas terhadap kelas penindas, sementara negara merupakan alat bagi kelas penindas terhadap lawan-lawannya dan upaya penghapusan ketidakadilan, ketertindasan dan eksploitasi secara kolektif jika perlu revolusioner merupakan kata kunci dalam marxisme.vi Dengan menempatkan dan mengorientasikan realitas sosial umat sebagai dase in dan upaya perombakkannya menuju masyarakat yang berkeadilan dan berkebebasan terlepas dari segala bentuk penindasan struktural yang dilahirkan oleh kekuasaan, merupakan sentuhan model kerja hermenutika, fenomenologi dan marxisme dalam alur pemikiran tafsir yang ditawarkan oleh Hasan Hanafi. Sedemikian rupa dapat dikatakan bahwa cara pandang Hasan Hanafi terhadap realitas sosial umat berada dalam konteks cara pandang terhadap dase in melalui tatapan hermeneutika filosofis dan fenomenologis dan apa yang mesti dilakukan dalam menatap cara pandang terhadap dasein tersebut melalui tatapan marxisme Kesemua ini dapat dikatakan sangat menyentuh alur pemikiran Hasan Hanafi dalam membangun suatu model penafsiran yang ingin ditawarkannya.

Melalui penafsiran atas teks-teks al-Qur`an seperti ini lah sesungguhnya Hasan Hanafi berupaya membentuk sebuah model penafsiran yang dapat menjadi landasan normatif, bahkan ideologis bagi perjuangan umat Muslim dalam menghadapi penindasan, eksploitasi dan ketidakadilan, baik yang dilancarkan dari luar Islam maupun dari dalam Islam itu sendiri, terutama dari penguasa-penguasa yang berlangsung di dalam masyarakat Muslim itu sendiri.vii

Dalam konteks seperti inilah Hasan Hanafi bersikeras menawarkan model penafsiran yang semestinya dilakukan oleh umat Islam umumnya dan para ilmuwan Muslim khususnya dalam rangka mengatasi segala ketertindasan dan keterbelakangan yang tengah menghimpit umat saat ini Secara tegas dapat dikatakan bahwa Hasan Hanafi menawarkan bagaimana semestinya realitas sosial dibaca memalui al-Qur`an yang bernuansa praktis, emansipatoris dan liberalis.

Namun demikian tidak pula dapat disangakal bahwa beragam kritikan telah pula banyak dialamatkan kepada Hasan Hanafi terhadap model penafsiran yang ditawarkannya, terutama adanya tendensi subjektif ideologis yang tidak dapat dilepaskan dalam model penafsiran yang ditawarkannya.viii

Beragam kritikan yang ditujukan kepada Hasan Hanafi tentang model tafsir yang ditawarkannya seperti yang dilontarkan oleh Nasr Abu Zayd dan Ali Harb seperti diungkap di atas dalam wacana akademis merupakan sesuatu yang tidak dapat dihindarkan. Hal ini dikarenakan perbedaan nuansa keilmuan yang dimiliki Nasr Abu Zayd dan Ali Harb yang berbeda. Nasr Abu Zayd 
umpamanya, keilmuan hermeneutikanya lebih didominasi oleh model hermenetika teoritis yang sangat berseberangan dengan model hermeneutika filosofis sebagai dasar hermenutika pembebasan yang diajukan oleh Hasan Hanafi. Demikian pula Ali Harb seorang pemikir kontemporer Mesir yang memiliki latar belakang pemikirannya pada "teori kritis' yang memang cenderung curiga akan tergayutnya suatu ideologis atau 'rasionalisasi teknologis' atas suatu pemikiran atau wacana yang digulirkan oleh seorang ilmuwan.

Namun di atas semua itu, menurut hemat penulis, kecurigaan yang bertendisius negatif terhadap hermenutika al-Qur`an yang ditawarkan oleh Hasan Hanafi, tidak lah dengan serta merta menghasilkan seperti yang dikhawatirkan oleh pengkritisi terhadap pemikirannya yang sangat sarat dengan nuansa subjektivitas dan ideiologitas seperti diungkap di atas. Kenapa, karena jika dicermati metodologis model hermeneutika al-Qur`an yang diajukannya, sejatinya diberangkatkan dari pencarian makna ontensitas atas makna teks, baik dari sisi cakupan kritik sejarah maupun muatan kritik eiditis sebagai piranti bagi pencarian makna objektif teks yang sangat ditekankan oleh Hasan Hanafi, bahkan dua kritikan ini termasuk dalam dua tahapan dari tiga tahapan model hermeneitika pembebasannya seperti yang akan dijelaskan nanti.

\section{Paradigma Hermenutika al-Qur`an Hasan Hanafi: Tahapan dan Metodologi Penafsiran}

Bagi Hasan Hanafi hermeneutika al-Qur’an merupakan ilmu yang menjelaskan penerimaan teks (wahyu) sejak dari tingkat perkataan sampai pada tingkat dunia. Ilmu tentang proses wahyu dari huruf sampai kenyataan, dari logos sampai praxis dan juga transformasi wahyu dari pikiran Tuhan sampai ke kehidupan nyata manusia. ${ }^{\text {x }}$

Dari paparan Hasan Hanafi ini, menunjukkan bahwa arus kerja dalam hermeneutika al-Qur'an tidak hanya sebatas pada wacana metodis-objektif sebagaimana yang diterapkan dalam hermeneutika teoritis seperti yang banyak dipraktekkan oleh oleh Fazlur Rahman, Muhammad Syahrur, Abu Zayd dan Muhmmed Arkoen, melainkan juga dalam arus wacana filosofis-emansipatoris Sedemikian rupa untuk yang terakhir ini menjadikan hermeneutikanya sangat bertendesius hermeneutika terapan yang merupakan bagian dari perjuangan sosial. ${ }^{x}$ Dalam konteks wacana terakhir ini pula lah pada dasarnya hermeneutika al-Qur'annya dilebeli dengan hermeneitika pembebasan sebagaimana banyak diberikan oleh para ahli seperti telah disinggung di atas.

Hermeneutika al-Qur’an yang berwatak praktis filosofis-emansipatoris ini diakui memang sangat mengental pada sebagian tahap kedua dan ketiga dari tiga tahapan kerja hermeneutika yang diajukannya, namun bukan berarti Hasan Hanfi mengabaikan hermeneutika teoritis yang mengklaim diri sebagai hermeneutika objektif- rasional dan universal, imun dari berbagai kepentingan dalam melakukan penafsiran sebagaimana akan kita lihat pada uraian di bawah ini.

Sementara itu perlu pula dicatat bahwa penamaan pembebasan bagi hermeneutikanya pada prinsipnya lebih ditujukan dari upayanya yang sangat 
kuat guna memaksimalkan fungsinalisasi al-Qur`an dalam menstransformasi realitas kehidupan umat manusia menjadi lebih baik, terbebas dari ketertindasan dan eksploitasi yang terstruktur, atau dapat juga dikatakan sebagai protes terhadap model penafsiran al-Qur'an yang tidak begitu relevan dengan problematika yang dihadapi umat, atau boleh jadi pelebelan ini secara faktual lantaran keinginanya untuk memperjuangkan semisal 'keadilan', 'kebebasan' dan menghapus 'penindasan', 'eksploitasi' dan ' kebodohan' sebagai realitas sosial umat saat ini.

Tiga alasan pelebelan hermeneutika Hasan Hanafi seperti di atas, paling tidak secara implisit dapat dicermati dari pernyataannya bahwa hermenutika konservatif beranjak dari teks, mendasarkan diri pada makna literal dan makna otonom dan aturan yang didasarkan pada realitas yang diandaikan, kemudian menganggap teks sebagai nilai per se. Sedangkan hermeneutika progresif, dalam hal ini pembebasan (penulis) menganggap teks sebagai alat, kehidupan nyata justru adalah nilai absolut yang perlu diperhatikan.xi

Sejalan dengan konsepsinya akan hermeneutika al-Qur'an seperti ini dan pendapatnya yang secara eksplisit mengatakan bahwa hermeneutika adalah ilmu yang menentukan hubungan antara kesadaran dan objek; maka hubungan kita dengan kitab-kitab suci dalam bentuk; 1) kita memiliki kesadaran historis yang dapat menentukan keaslian teks dan tingkat kepastiannya, 2) kita memiliki kesadaran eiditik yang menjelaskan makna teks dan menjadikannya rasional, 3) kesadaran praktis yang menggunakan makna tersebut sebagai dasar teoritis bagi tindakan dan mengantarkan wahyu pada tujuan akhirnya dalam kehidupan manusia dan di dunia ini sebagai struktur ideal yang mewujudkan kesempurnaan dunia,xii Dari tiga bentuk hubungan seperti ini, dapat disimpulkan bahwa ditemukan ada tiga wilayah kerja dalam hermeneutika alQur`an yang ditawarkannya, yaitu pertama; kritik historis, kedua; kritik eiditis dan ketiga; kritik praksis.

Pertama: Kritik Historis; wilayah kerja yang pertama ini dimaksudkan oleh Hasan Hanafi untuk menemukan otensitas teks yang disampaikan Nabi Muhammad SAW kepada umatnya dalam kesejarahan. Bagi Hasan Hanafi hermeneutika sebagai kritik teks baru bekerja pada wilayah ketika Nabi Muhammad SAW menyampaikan wahyu in verbatim kepada manusia, bukan pada wilayah ketika Tuhan menyampaikan wahyu in verbatim kepadan Nabi Muhammad SAW. Tegasnya bahwa hermeneutika tidak berurusan dengan sifat hubungan antara Tuhan dan Rasul-Nya dan bagaimana Nabi menerima wahyu tersebut, melainkan pada kata-kata yang diturunkan dalam kesejarahan.xiii Dengan demikian dapat dikatakan bahwa wilayah kerja hermeneutika terletak pada dimensi horizontal wahyu yang sifatnya historis dan bukan pada dimensi vertikal yang sifatnya metafisis.

Pentingnya kritik historis dilakukan terhadap teks menurut Hasan Hanafi, lantaran penafsiran yang baik, bahkan penerapan hasil penafsiran itu mesti didahului oleh pembuktian keasliannya. Melalui pembuktian ontensitas teks ini lah penafsiran dari teks yang palsu dapat dihindarkan, karena akan menjerumuskan pada kekeliruan, sekalipun tafsirannya benar dari kandungan teks palsu itu. xiv 
Jadi dapat dikatakan bahwa kritik historis merupakan tahap awal yang menentukan dalam wilayah kerja hermeneutika al-Qur`an, bahkan sebagai prasyarat sebelum melakukan penafsiran terhadap teks untuk mendapatkan pemahaman makna dari teks tersebut.

Kedua; Kritik Eidetis; wilayah kerja yang kedua ini bergerak dalam proses interpretasi, bahkan pada wilayah kerja kedua ini lah bagi Hasan Hanafi sesungguhnya hermeneutika dalam pengertian pemahaman bisa dimulai Materi perbincangan hermeneutika pada wilayah ini di antaranya meliputi bahasa dan Asbab an-Nuzul, yang melahirkan teks segera diikuti dengan proses menyadari makna teks ini dalam kehidupan manusia. ${ }^{\mathrm{xv}}$

Memperhatikan kata eidetis yang dipakai oleh Hasan Hanfi untuk tahap kedua, secara eksplisit dapat dikatakan bahwa kinerja hermeneutika yang diimplementasikannya paling tidak berwarna fenomenologis.xvi Dengan pemakaian istilah teknis fenomenologi ini paling tidak dapat dipahami bahwa kuatnya keinginan Hasan Hanafi untuk menempatkan teks seutuhnya sebagaimana yang ditangkap oleh kesadaran penafsir untuk memperoleh makna sejatinya tentang teks tesebut.

Pemahaman penulis terhadap keinginan Hasan Hanafi seperti diungkapkan di atas semakin meyakinkan bila dikonfirmasikan dengan pendapatnya bahwa suatu penafsiran harus menghindarkan diri dari pengulangan-pengulangan prasangka tertentu dari dogma, karena akan membawa penafsiran ke dalam dugaan-dugaan semata. Oleh karena itu menurutnya seorang penafsir harus memulai pekerjaannya dengan tabularasa, tidak boleh ada yang lain kecuali analisis linguistiknya.xvii Tabularasa dalam kesadaran ini menurutnya mesti dipahami dalam spektrum fenomenologi, yakni yang selalu terarah pada realitas yang bermakna sebagai 'intensionalitas', yaitu ' kesadaran akan sesutu' dan juga kesadaran yang 'mengkonstitusi' realitas, yaitu sebagai proses tampaknya realitas pada kesadaran. Dengan demikian kesadaran dalam fenomenologi sejajar dengan realitas. xviii Bagaimana aplikasi penafsiran dalam bentuk ini sesungguhnya, terlebih lagi dikaitkan dengan kritik praktis dalam hermeneutika al-Qur`an yang diajukannya sebagai terobosan baru dalam pembacaan teks dan realitas, akan diuraikan nanti dalam bagian tersendiri, yakni teori interpretasi.

Aplikasi kritik eidetis menurut Hasan Hanafi berada pada tiga tahap analisis, yakni pertama analisa bahasa, kedua analisa konteks sejarah dan ketiga generalisasi.

Pertama; analisa bahasa. Menurut Hasan Hanafi analisa bahasa mencakup morfologi, leksikologi dan sintaksis. Dimaksudkan dengan morfologi adalah analisa yang bertujuan menjelaskan bentuk kata beserta implikasi maknanya akibat perbedaan penggunaan kata. Leksikologi di lain pihak, dimaksudkan menjelaskan jenis-jenis makna seperti makna etimologis, makna biasa dan makna baru. Makna etimologis ialah makna dasar, makna biasa ialah makna yang mengikat wahyu pada penggunaan kata dalam suatu masyarakat, ruang dan waktu tertentu. Makna biasa ini lah yang membuat wahyu sesuai dengan yang dimaksud oleh situasi khusus. Makna baru yang diberikan wahyu adalah makna yang tidak terkandung dalam makna etimologis, maupun pada makna biasa. Makna baru ini berfungsi memberi petunjuk bagi tindakan dan 
merupakan dorongan baru bagi manusia. Oleh karena itu kandungan maknanya sama sekali bebas dari hal-hal yang misterius, tetapi justru merupakan makna alamiah, rasional dan jelas. Maksud makna baru ini adalah untuk membebaskan manusia dari usaha-usaha mencari teori agar manusia dapat memusatkan diri dan perhatian pada hal-hal praktis. ${ }^{\text {ix }}$ Sedangkan analisa sintaksis yang merupakan kunci sesungguhnya dari kegiatan penafsiran, bertujuan menyingkap prinsip-prinsip makna ganda dalam teks seperti makna harfiah dan kias, istilah-istilah univokal dan ekuivokal, makna samar dan tepat, makna yang tampak dan yang tidak, makna yang jelas dan tersembunyi, makna khusus dan makna umum, larangan atau perintah. $x x$

Kedua; analisa konteks sejarah. Analisa tahap ini difokuskan pada latar belakang sejarah yang melahirkan teks. Menurutnya terdapat dua jenis situasi, yakni 'situasi saat' atau 'contoh situasi' dan 'situasi sejarah'. Situasi saat atau contoh situasi ini adalah kasus dimana teks diturunkan yang menjadi subtratum bagi wahyu. Dalam wahyu yang ditulis in verbatim, situasi tersebut adalah situasi saatnya. Sementara situasi sejarah terjadi ketika teks tidak ditulis in verbatim atau yang ditulis bukan berupa wahyu tetapi inspirasi mengenai wahyu, (seperti komentator dalam Hadis) tertentu dalam sejarah yang ditulis oleh para penulis wahyu pada masa berikutnya. xxi

Ketiga; generalisasi. Setelah makna linguistik dan latar belakang sejarah ditemukan, selanjutnya ditentukan generalisasi. Generalisasi di sini berarti menganggap makna dari situasi saat dan situasi sejarahnya agar dapat menimbulkan situasi-situasi lain. Pada tahap terakhir ini Hasan Hanafi menginginkan diperolehnya makna baru dari kegiatan penafsiran yang berguna untuk menyingkap beragam kasus-kasus spesifik dalam kehidupan masyarakat. Di sini lah penjelasan berperan setelah adanya penafsiran. Setelah melakukan penjelasan harus pula melakukan generalisasi pada tingkat paling eksrtim dan jangan sampai terperosok dalam perbedaan esoterik, sebab generalisasi masih tetap diawasi dalam aturan-aturan gramatikal. xxii

Dari uraian di atas terlihat bahwa analisa bahasa dan analisa kontekas sejarah yang masing-masing sebagai tahap pertama dan kedua pada kritik eiditik dapat dikatakan semisal telaah yang diinginkan dalam hermeneutika teoritis-objektif. Dalam konteks ini dapat dikatakan pula bahwa sesungguhnya Hasan Hanafi mengandaikan adanya makna awal sebagai makna sejati pada teks yang bersifat objektif dan universal yang mesti digali oleh penafsir. Ini juga menunjukkan Hasan Hanafi sangat tidak menginginkan hermeneutika bukan semacam rekayasa kemauan si penafsir dalam memahami teks. Sehubungan dengan ini dapat pula dikatakan bahwa geliat fenomenologi telah memberi alur dalam pemikiran hermeneutikanya, sampai pada titik ini Hasan Hanafi menunjukkan dirinya sebagai seorang hermeneutik teoritik dan metodis

Namun demikian di atas itu semua, perlu pula digaris bawahi pada tahap kritis eidetis ini, tepatnya pada analisa konteks sejarah teks, Hasan Hanafi telah membuka ruang bagi konteks penafsir. Hal ini di antaranya lebih dikarenakan sebagai implikasi teoritis fenomenologisnya yang mengatakan bahwa kesadaran penafsir dan realitas adalah sejajar. Artinya realitas memiliki hak yang sama dengan penafsir di hadapan teks, sedemikian rupa problema-problema masyarakat sebagai realitas sosial menjadi preferensi teks Dalam konteks seperti 
ini lah nantinya dapat dipahami kenapa menurutnya penafsiran itu bukan lagi dalam bentuk reproduksi makna, tetapi dalam bentuk produksi makna baru yang praktis-emansipatoris seperti yang diinginkan pada tahapan genaralisasi .Karakteristik penafsirannya seperti ini semakin mengental pada tahapan kritik praksis sebagai tahap terakhir dalam hermeneutika al-Qur`annya.

Ketiga Kritik Praksis; Sebagai tahapan terakhir dalam hermeneutika alQur’annya, kritik praksis ini bagi Hasan Hanafi dapat diandaikan sebagai buah yang mesti digenggam bagi fungsionalisasi hermeneutika al-Qur`an yang digagasnya.Bahkan hermeneutika al-Qur`annya yang disebut sebagai hermeneutika pembebasan, sangat antusias pada transformasi masyarakat yang pada dasarnya terletak pada kritik praksis ini sekalipun tidak dapat pula dipungkiri bahwa derasnya lontaran kritik yang dialamatkan kepadanya seperti telah diungkap di muka pada dasarnya tertuju pada kritik praksisnya ini.

Rasionalisasi kritik praksis ini sedemikian urgen dan strategis di mata Hasan Hanafi di antaranya oleh keyakinan teologisnya yang kuat bahwa wahyu al-Qur`an sebagai dasar dogma merupakan motivasi bagi tindakan di samping sebagai objek pengetahuan..Bahkan baginya tataran praxsis merupakan penyempurnaan kalam Tuhan di dunia ini, mengingat tidak ada kebenaran teoritis dari sebuah dogma atau kepercayaan yang datang begitu saja, karena dogma lebih merupakan suatu gagasan atau motivasi yang ditujukan untuk praksis.xiii Baginya pembuktian akan adanya Tuhan tidak perlu membuktikan eksistensinya kecuali sebagai pengenalan terhadap sabda-sabdanya dalam kehidupan dunia. Tuhan sebagai persona oleh Hasan Hanafi diletakkan dalam tanda kurung (apoche') sehingga teologi positif tidak lagi berurusan dengan fakta intuisi atau aturan, tetapi pada transformasi wahyu dari teori ke praktik. xxiv

Kecuali itu, rasionalisasi empiris-faktual metodologis juga menjadi dorongan yang kuat baginya untuk menampilkan konstruksi hermeneutika alQur`an. Berangkat dari keyakinan praktisnya tentang teori penafsiran al-Qur`an yakni merupakan upaya pemahaman terhadap al-Qur'an yang mampu mengungkapkan kepentingan masyarakat, kebutuhan kaum muslimin dan isuisu kontemporer, ${ }^{x \times v}$ menjadikan penafsiran al-Qur'an sejatinya berada dalam bentuk penafsiran otoritatif dengan prinsip-prinsip ilmiah yang terarah pada kepentingan tertentu. ${ }^{\text {xvi }}$ Bahkan secara ekstrim dikatakanyya menafsirkan teks dalam situasi kontemporer sepenuhnya merupakan kegiatan produktif. Ia adalah eksplikasi makna-makna baru dari teks, tidak soal apakah maknanya sesuai atau tidak dengan makna asli, juga tidak penting apakah konteks situasionalnya sama atau berbeda. Pandangannya seperti ini diklaimnya sebagai proyeksi masa kini ke dalam masa lalu, atau kembali ke esensi dan metode retroaktif..xxvii

Model penafsiran seperti yang dikehendakinya ini sangat berbeda dengan model penafsiran yang telah berkemabang selama ini baik dalam bentuk tafsir tradisional yang berorientasi tekstual, seperti tafsir tahlili, atau model tafsir yang menempatkan al-Qur’an sebagai justifikasi bagi limu-ilmu keislaman, kesemuanya ini tidak lagi relevan bagi kepentingan masyarakat kontemporer.xxvii Bahkan dalam rumusan yang kategoris, Hasan Hanafi membeberkan kelemahan model penafsiran al-Qur`an yang ada saat ini, yakni 1) lebih mempertimbangkan persoalan-persoalan teologis daripada antropologis, 2) 
bersifat afirmatif terhadap realitas sosial dari pada untuk mentrasformasikannya, dan 3) tidak berangkat dari kritik pembaharuan yang substantif terhadap unsur-unsur negatif dalam Islam kecuali pembaharuan yang berasal dari luar teks-teks keagamaan dan melibatkan banyak kepentingan kelompok, ekonomi, politik dan pemikiran tertentu. xxix

Dari konstruksi hermeneutika al-Qur'an pada tahapan kritik praksis seperti ini, sangat jelas menunjukkan bahwa nuansa hermeneutika filosofis benar-benar diaplikasikannya secara utuh pada kritik praksis sebagai tahapan akhir hermeneutika al-Qur`an yang diinginkannya. Dengan kritik praksis ini lah sesungguhnya Hasan Hanafi menggantungkan harapannya untuk mentransformasi umat khususnya masayarakatnya yang terbelenggu oleh kekuasaan yang tidak mencerahkan. Hal seperti ini juga cukup mudah untuk dipahami kenapa Hasan Hanafi begitu bersikeras menampilkan hermeneutika sebagai metoda interpretasi dalam sosok pencarian makna produktif-kreatif, emansipatoris-ideologis, bukan objektif, rasional dan universal. Sosok hermenutika seperti ini setidaknya terindikasi dari ungkapannya bahwa penafsir lah yang menentukan pilihan makna.bagi teks, ${ }^{x \times x}$ dimaksud dengan emansipatoris-ideologis terrefleksi dari penilaiannya bahwa penafsir dan penulis teks sama-sama berada dalam tindakan ideologi, oleh karena itu baik penafsir maupun penulis teks memproyeksikan diri ke dalam teks, mencari kepentingannya dan menjadikan teks sebagai justifikasi bagi berbagai tindakan sosial. $x x x i$

Dari tiga wilayah kerja hermenutika al-Quran yang digagas oleh Hasan Hanfi juga diketahui bahwa baginya hermenutika meliputi teoritis-objektif dan filosofis-praktis, sekalipun kelihatannya tanpa disadarinya yang terakhir ini merupakan sosoknya yang paling mencuat pada hermeneutika al-Qur`an yang digagasnya.

\section{Metodologi Penafsiran Hermeneutika al-Qur`an}

Berangkat dari keprihatinnya terhadap model penafsiran al-Qur'an tradisional yang lebih bercorak di antaranya pada pengabdian yang utuh pada disiplin ilmu-ilmu keislaman klasik seperti fighi, bahasa, teologi, filsafat daripada memahami al-Qur`an secara sungguh-sungguh, atau model tafsir tahlili yang melahirkan penafsiran yang parsial, bercampur baur satu tema dengan tema lainnya, tanpa ada satu akumulasi makna yang fungsional bagi terciptanya konsep global yang terfokus, sehingga tercerabut dari kebutuhan jiwa dan kepentingan masyarakat kontemporer, xxxii atau besarnya jurang antara teori tradisional ilmu-ilmu al-Qur’an dengan realitas kekinian yang tengah dihadapi umat, ${ }^{x x i i i}$ atau tidak ditemukannya suatu teori penafsiran yang otoritatif dengan prinsip-prinsip ilmiah yang terarah kepada kepentingan tertentu, ${ }^{\text {xxiv }}$ atau model tafsir bi al-ma'tsur yang hanya melahirkan makna hipotetis, lantaran penarikan makna didahului oleh pemikiran murni, kemudian pemberian justifikasi baik berdasarkan riwayat maupun argumen pikiran. Demikian pula pada tafsir bi al-ma qul yang tidak kalah hipotetisnya, sebab makna yang 
diperoleh secara hipotetis tidak mungkin menjadi positif hanya dengan argumen yang sama-sama hipotetis pula. ${ }^{x \times x v}$

Berdasarkan kekurangan model penafsiran al-Qur’an seperti dipaparkannya itu, maka Hasan Hanafi menginginkan adanya semacam penafsiran yang tidak lagi hanya berpihak pada pencarian makna teks objektif, yang terlalu membatasi diri pada aspek tekstualitas al-Qur`an yakni kebahasaan dan sejarah turunyanya makna yang akan mereduksi makna, atau hilanya jurang antara teori ilmu-ilmu al-Qur`an dengan kebutuhan umat, atau tidak tersoburdinasinya makna al-Qur`an untuk kepentingan ilmu-ilmu keislaman yang lain, atau lahirnya penafsiran al-Qur'an yang rasional, riil yang menyajikan argumennya dari luar bukan dari dalam yang dapat melahirkan suatu ideologi yang koheren dan suatu pandangan dunia yang menglobal, beranjak dari partikular pada keseluruhan. Singkatnya model penafsiran al-Qur’an yang diinginkan oleh Hasan Hanafi adalah penafsiran yang sangat berpihak pada kepentingan penafsir dan realitas umat.

Guna mengatasi berbagai kekurangan model penafsiran al-Qur`an yang ada serta mewujudkan model penafsiran yang benar-benar berpihak kepada realitas umat maka dibutuhkan seuatu bentuk apa yang disebutnya dengan hermeneutika soaial atau metode tafsir maudhu $i$, yang secara operasional disebutnya penafsiran gerak ganda, yakni dari teks menuju realitas dan dari realitas menuju teks; Yang pertama diterapkan melalui prinsip-prinsip ampibilogis bahasa, sementara yang kedua melalui sensitivitas zeitgeist (semangat zaman). ${ }^{\mathrm{xx} x \mathrm{ri}}$.

Untuk memahami kinerja hermeneutika al-Qur`an yang ditawarkan Hasan Hanfi ini, perlu dipahami beberapa premis yang diajukannya yaitu;

1.Posisi wahyu pada aphoce, artinya tidak ditolak dan tidak pula diafirmasi. Penafsir tidak perlu lagi mempersoalkan apakah al-Qur`an dari Tuhan ataukah dari Muhammad SAW. Penafsiran tematis memulai dari teks apa adanya Pertanyaan yang dimunculkan adalah 'apa' dan bukan 'bagaimana' tentang teks. Pada interpretasi, teks adalah teks, tidak masalah apakah ia Ilahiyah ataukah human, sakral atau profan, relijius atau sekuler. Pertanyaan asal usul adalah permasalahan kejadian teks, sementara penafsiran berkaitan dengan isi teks. xxxvii

2.Al-Qur’an diposisikan seperti layaknya teks-teks lain yang ditafsirkan berdasarkan aturan-aturan yang sama. Pemisahan antara teks suci dan profan hanya ada dalam praktek kegamaan dan bukan bagian dari hermeneutika umumnya. Al-Qur`an seperti halnya Hadis merupakan trasfigurasi bahasa manusia, ia mencakup bahasa Arab dan non Arab. Berisikan ucapan orang beriman maupun orang kafir.xxxviii

3. Tidak ada penafsiran palsu atau benar, pemahaman benar atau salah, tetapi yang ada hanyalah perbedaan pendekatan terhadap teks yang ditentukan oleh perbedaan kepentingan dan motovasi. Oleh karena itu konflik interpretasi mencerminkan pertentangan kepentingan, termasuk interpretasi lingusitik

4.Tidak ada penafsiran tunggal terhadap teks, tetapi penafsiran plural yang disebabkan oleh perbedaan pemahaman para penafsir. Teks hanyalah alat kepentingan, bahkan ambisi manusia. Teks hanyalah bentuk, penafsir lah 
yang memberinya isi sesuai ruang dan waktu dalam masa mereka. Penafsiran konservatif melanggengkan status quo, penafsiran revolusioner berusaha untuk mengubahnya. xxxix

Dari beberapa premis yang ditawarkannya tersebut di atas sangat terlihat bahwa selain merupakan protesnya terhadap kinerja penafsiran tradisional dan penfsiran model hermeneutika teoritis, juga menunjukkan betapa Hasan Hanafi menginginkan al-Qur`an benar-benar fungsional bagi kehidupan umat dalam konteks problema historisitas yang menghimpitnya. Kecuali itu, sesungguhnya nuansa hermeneutika filosofis dan kritis yang akhirnya bermuara pada model penafsiran kritis-sosial sangat mengental dalam tawaran hermeneutika al-Qur’annya. Dalam hal ini dapat dikatakan bahwa Hasan Hanafi benar-benar telah melepaskan baju hermeneutika teoritis yang pada awal dipakainya.

Premis-premis di atas juga menunjukkan bahwa kinerja penafsiran memang mesti berpihak pada realitas bukan pada pencarian makna objektif sejatinya dari teks al-Qur`an. Dalam hal seperti ini sesungguhnya dapat dipahami kenapa Hasan Hanfi menempatkan realitas sebagai sesuatu yang sentralistis dan suprematis dalam kinerja penafsiran al-Qur`an. Sedemikian rupa adalah sangat mudah pula dipahami kenapa Hasan Hanafi menempatkan semisal konsep asbab al-nuzul, nasikh-mansukh dan mashlahah sebagai dasariah motivasional-logis bagi hermeneutikanya. ${ }^{x l}$

Dari relasi yang amat kuat antara wahyu dan realitas dalam pemikiran Hasan Hanafi seperti diungkap di atas, sekaligus menunjukkan pula bahwa adanya kecenderungan meninggalkan hermeneutika teoritis dan metodis menuju hermeneutika filosofis yang cenderung ke praksis yang terimplementasi dengan amat jelas pada konsepnya hubungan yang kuat antara wahyu dan realitas, interperetasi dan aksi serta teori dan praktik dengan menempatkan dominasi penafsir ketimbang teks itu sendiri seperti diungkap di atas.

\section{Skema Eksistensialitas Hermeneutika al-Qur`an}

Semua premis penafsiran yang diajukan oleh Hasan Hanafi seperti di atas pada dasarnya tidak dapat dipisahkan dari posisi penafsir yang ditempatkannya sebagai subjek yang memiliki kepentingan terhadap teks, bukan sebaliknya sebagaimana yang diajukan oleh para hermeneutika teoritis seperti Fazlur Rahman, Muhammed Arkoen, Abu Zayd dan lain-lainnya

Pada tahapan hermeneutika praksis-kritis, sebagai ujung tombak hermeneutika pembebasannya, Hasan Hanafi benar-benar telah memposisikan penafsir dihadapan teks sedemikian kuat dan sentris, bahkan melampaui dari apa yang digagas oleh para hermeneutika filosofis seperti Gadamer dan Marthin Heidegger xli di antara tokoh yang dirujuknya.

Kuat dan sentrisnya posisi penafsir ini sesungguhnya tidak dapat dilepaskan dari ketidakpuasannya akan skema model penafsiran tradisional yang telah berlangsung begitu lama di dalam wacana keilmuan keislaman, seperti skema teologis; hubungan triadik antara hakekat, sifat dan perbuatan dalam teologis Asy`ariyah, lima prinsip dalam teologis Mu`tazilah, atau skema 
logika, fisika dan metafisika dalam trilogi filsafat, atau skema kondisi dan tingkat dalam sufisme, atau skema ritual dan hubungan - hubungan sosial dalam fiqhi dan sebagainya. Hasan Hanafi menawarkan yang sama sekali berbeda dengan skema-skema yang dilakukan oleh penafsir al-Qur`an tersebut, bahkan tidak jarang pula skema-skema tersebut terkait pula dengan suatu orde, sistem dan ideologi tertentu. ${ }^{x l i i}$

Berangkat dari kecenderungan pemikiran fenomenologisnya dan maxismenya, secara teoritis Hasan Hanafi menampilkan skema penafsiran yang berpusar pada tiga lingkaran konsentris dengan kesatuan pusat being, sein (meng-ada), mitsein (meng-ada dengan yang lain) dan aussein, in-der-welt sein (meng-ada dalam dunia).xliii

Menurut Hasan Hanafi kesadaran individu sebagai lingkaran kosentris yang paling dalam menggambarkan pusat dunia. 'Ada' sebagai besinnung merupakan cogito ergo sum. Dalam bahasa Fitche, the self (ego) menempatkan diri berhadap-hadapan dengan dunia eksternal. Ego identik dengan diri sebagai kesadaran, sebagai pemberian pertama, kegiatan kesadaran, perasaan, dan pencerahan. 'Ada' adalah ada yang menyadari dan bukan hanya ada secara material. Penemuan diri adalah cogito tahap kedua. Yang pertama adalah kesadaran akan waktu, dan yang kedua adalah kesadaran dalam ruang. Kesadaran individual adalah keseluruhan dunia termasuk kepekaan eksternal dan internal,sensasi, persepsi, kognisi, emosi, motivasi, inklinasi, aksi dan sebagainya. Interioritas adalah prasyarat eksterioritas dalam pengetahuan dan tindakan.

Sementara lingkaran kedua yakni ada bersama yang lain' menunjukkan sifat sosial, intersubjektivitas, dan dunia manusia, relasi individu dengan individu lain boleh jadi dalam bentuk perkawinan kebapakan, keibuan, kasih sayang persaudaraan dan persahabatan. Hubungan-hubungan politik melipiti relasi rakyat dengan negara. Hubungan ekonomi memanipestasikan dalam hubungan-hubungan produksi, perdagangan, upah, harga, keuntungan, eksploitasi, monopoli, kepemilikan dan kontrak. Relasi sosial mencakup juga kesetaraan, keadilan sosial, kejujuran dan sebagainya.

Terakhir 'ada dalam dunia' merujuk pada hubungan kesadaran individu akan alam, dunia benda-benda. Alam diciptakan demi keberlangsungan hidup manusia. Alam penuh tanda yang menunjukkan asal usul dan signifikansinya. Ia ditujukan untuk manusia. 'Ada dalam dunia' ini juga merujuk pada langit, cakrawala, matahari, bulan dan bintang, angin, awan dan burung-burung, termasuk juga sungai, mata air, sumur dan lautan dan tumbuh-tumbuhan seperti tanaman, lembvah, sawah, buah-buahan dan sebagainya. Hewan juga termasuk bagian dari alam. Manusia sekalipun tidak lepas dari alam, di dalam dirinya ada bagian yang bersifat alamiah; tubuh, kebutuhan material dan kegiatan dunia.xliv

Dari paparan skema eksistensial penafsiran yang ditampilkan oleh Hasan Hanafi di atas sangat menunjukkan betapa kuatnya posisi penafsir sebagai subjek terhadap teks. Baginya, penafsir merupakan pusat segala-galanya, tidak hanya pusat bagi dirinya, tetapi juga pusata bagi orang lain dan bahkan ia menjadi pusat dalam keberadaan di alam jagad raya. Dalam konteks logika 
fenomenologisnya seperti ini lah dapat dipahami, kenapa Hasan Hanafi sesungguhnya memposisikan penafsir sebagai subjek terhadap teks.

Dari model skema penafsiran yang menempatkan penafsir sebagai subjek di satu sisi dan realitas sosial di sisi lainnya, menjadikan Hasan Hanafi memposisikan teks pada pembenaran suatu pemikiran dalam rangka memecahkan problematika realitas ke arah transformatif. Dalam hal ini dalam dikatakan bahwa penafsiran tentunya bersifat praksis dan ideologis.

Dari skema penafsiran seperti yang dipaparkannya di atas, secara lebih spesifik Hasan Hanafi menetapkan karakteristik penafsiran al-Qur`an yaitu:

1.Penafsir harus mampu menghasilkan tafsir yang spesifik. Artinya menafsirkan ayat tertentu al-Qur'an dan bukan menafsirkan keseluruhan teks. misalnya jika yang dibutuhkan adalah pembebasan bangsa dari kolonialisme, maka penafsiran yang dilakukan adalah ayat-ayat perang ketimbang ayat-ayat lain.

2.Tafsir semacam ini disebut dengan tafsir tematik, mengingat tidak menafsirkan al-Qur'an berdasarkan kordasinya, tetapi lebih menafsirkan keseluruhan ayat al-Qur`an dalam tema-tema tertentu.

3.Penafsirran bersifat temporar. Yakni penafsiran yang berorientasi sosial bukan pada proses pencarian makna universal, tetapi diarahkan untuk memberikan gambaran tertentu dari keinginan al-Qur`an bagi generasoi tertentu. tafsir semacam ini tidak berurusan dengan masa lalu atau masa datang, tetapi dikaitkan dengan realitas temporer di mana ia muncul.

4.Penafsiran semacam ini berkarakter realistis. Artinya memulai penafsiran dari realitas kaum muslimin, kehidupan dengan segala problematikanya, krisis dan kesengsaraan mereka dan bukan tafsir ytang tercerabut dari masyarakat.

5.Penafsiran ini juga berorientasi pada makna tertentu dan bukan merupakan perbincangan retorik tentang huruf dan kata. Hal ini karena wahyu pada dasarnya memiliki tujuan, orientasi dan kepentingan, yakni kepentingan masyarakat dan hal-hal menurut akal yang bersifat manusiawi, rasional dan natural.

6. Tafsir ini juga bersifat eksprimental. Artinya ia adalah tafsir yang sesuai dengan kehidupan dan pengalaman hiduip penafsir. sebuah penafsiran tidak mungkin terwujud tanpa memperoleh pendasarannya pada pedngalaman penafsir yanf eksistensial.

7. Perhatian pada problem kontemporer. Seorang penafsir tidak dapat memulai penafsirannya tanpa dimulai dengan perhatian akan masalahmasalah kehidupan.

8.Posisi sosial penafsir, artinya posisi seseorang dalam kapasitasnya sebagai mufassir ditentukan secara sosial sekaligus menentukan corak penafsiran yang dilakukannya. Penafsiran adalah bagian dari struktur sosial, apakah penafsir merupakan bagian golongan atas, menengah atau bawah.xlv

Untuk dapat bekerja hermeneutika al-Qur`an seperti ini, Hasan Hanafi menetapkan beberapa aturan metodis atau prosedur interpretasi sebagai petunjuk ketika penafsiran dilakukan, yakni:

1. Merumuskankan komitmen sosial politik Penafsir sebagai bagian dari orang yang berada dalam krisis masanya, turut mengalami penderitaan dan 
terobsesi bagi perubahan sosial, maka menjadikannya sebagai seorang reformis, aktor sosial dan revolusioner, juga menjadikannya bukan lah seorang yang netral tetapi ia memiliki komitmen tertentu

2. Mencari sesuatu, artinya seorang penafsir tidak memulai penafsiran dengan tangan kosong atau tanpa mengetahui apa yang ingin ia ketahui terlebih dahulu. Ia mesti berpihak. Ia mencari solusi atas masalah. Kesadaran adalah kepentingan itu sendiri, sementara hikmah yang terkandung dalam asbab al-nuzul menggambarkan prioritas realitas atas teks. pertanyaan atas jawaban, stimulus atas respon.

3. Seorang penafsir berusaha mensinopsiskan ayat-ayat yang berkaitan dengan tema-tema tertentu Setiap ayat yang konsen dengan tema tertentu di kumpulkan dibaca secara simultan dan dipahami berulang-ulang hingga orientasi umumnya ditemukan.

4. Mengklasifikasikan bentuk-bentuk linguistik Tampilan pertama dari makna adalah melalui analisa linguistik, karena bagi Hasan Hanafi bahasa sebagai bentuk pemikiran membawa penafsir ke dalam makna

5.Membangun struktur. Setelah bentuk-bentuk linguistik memberi orientasi makna, penafsir berusaha membangun suatu struktur beranjak dari makna menuju suatu objek. Makna dan objek adalah sisi koin yang sama, dua faset intensionalitas yang serupa Makna adalah objek yang yang bersifat subjektif, sedangkan objek adalah subjektif yang objektif. Keduanya adalah korelasi yang sama dalam kesadaran.

6. Analisa situasi faktual. Setelah membangun suatu tema sebagai struktur ideal penafsir menggabungkan dan menghubungkannya dengan situasi nyata seperti kenyataan penindasan, hak-hak asasi manusia,.kekuasaan, kesejahteraan gunba mengetahui status kuantitatif masalah

7. Membandingkan yang ideal dan yang riil. Setelah membangun struktur ini, penafsir memberikan tema kualitatif dan analisa fakta sosial memberikan status kuantitatif sebagai fenomena sosio-historis. Penafsir membandingkan struktur ideal yang diiduksi dari analisis isi teks dan situasi faktual yang diinduksi oleh statistik dalam ilmu-ilmu sosial.

8. Mendiskripsikan model-model aksi. Sekali ditemukan adanya kesenjangan antara dunia ideal dan dunia riil maka aksi sosial merupakan langkah berikutnya dari proses interpretasi. Penafsir mentrasformasikan diri dari teks ke aksi dari teori ke praktek dari pemahaman ke perubahan Logos dan praksis menyatu dalam menjembatani jarak antara idealitas dan realitas dengan menemukan media komunikasi antara kedua dunia tersebut, mengubah realitas dan mengakomodasi yang ideal. Bagi Hasan Hanafi dalam rangka transformasi ini tindakan gradual sangat diperlukan untuk mencegah tindakan yang melompat pada kekerasan. xlvi .

Dari paparan di atas terlihat secara jelas bahwa hermeneutika al-Qur`an yang ditawarkan Hasan Hanafi benar-benar menempatkan penafsir dan realitas pada posisi yang sangat menentukan. Penafsir dituntut untuk dapat secara cerdas membentuk struktur ideal kemudian merealisaikannya dalam kehidupan nyata melalui interpretasinya terhadap teks al-Qur'an. Sementara realitas menjadi acuan utama ke arah penafsiran suatu teks. Pemahaman yang sungguhsungguh terhadap realitas oleh penafsir merupakan awal prapaham penafsir 
yang mesti dibawanya dalam proses penafsiran. Artinya keberpihakan penafsir yang kuat pada realitas guna mentransformasi-kanya merupakan sesuatu yang sangat diperlukan, karena proses penafsiran itu sendiri berujung pada praksisaksi

\section{Hermeneutika al-Qur`an Hasan Hanafi dalam Aksiologis-Etis: Sebuah Refleksi Konsekuensi}

Keinginan untuk menata umat ke arah yang lebih bermartabat melalui penafsiran teks-teks al-Qur`an, memang telah menjadi komitmen bagi hampir pemikir Islam dari dahulu hingga sekarang, tetapi mewujudkan keinginan tersebut dalam sebuah aksi sosial yang kongkrik, metodis dan praktis, boleh jadi, merupakan milik segelintir para pemikir kontemporer semisal Hasan Hanafi dan beberapa pemikir Muslim kontemporer lainnya.

Keinginan yang kuat Hasan Hanafi dalam hal seperti ini sesunguhnya tidak dapat dilepaskan dari kegelisahannya terhadap model penafsiran alQur`an yang ada saat ini yang dinilainya kurang memadai, bahkan irrelevan dengan kebutuhan umat yang segera untuk diperbaiki. melalui penafsiran teksteks al-Qur`an dalam konteks kebutuhan kekinian, kedisinian dan berkeadilan.

Terobsesi dari keinginannya yang amat kuat untuk melakukan transformasi-aksi umat yang membebaskan dan mencerahkan, menjadikan hermeneutika al-Qur`an yang digagasnya, agak cenderung mengabaikan makna sejatinya dari teks sebaliknya tidak jarang lebih mengedepankan prapaham penafsir yang sangat terbuka penyusupan dan menguatnya kepentingan ideologis dalam prapaham penafsir tersbut. Sedemikian rupa menjadikan posisi realitas dan penafsir melebihi teks dalam hal ini al-Qur`an sebagai rujukan transformasi yang diinginkanya

Apa yang digagas oleh Hasan Hanafi dalam hermeneutikanya seperti ini segera memunculkan kekhawatiran akan posisi teks yang sangat mudah terreduksi dan tersubordinasi pada realitas dan penafsir yang sangat rentan akan keberpikan dan kepentingan yang boleh jadi sangat bersifat teleologis-etis; khair li khairihi ketimbang deontologis - etis, khair li zatihi, xlvii atau praksis parsial ketimbang praksis - global.

Diakui memang bahwa dalam wacana aksiologis-etis problematika penetapan 'baik' atau 'tidak baik' di kalangan filsuf Muslim mengakui adanya dua bagian, yakni yang pertama biasanya disebut dengan khairu li zatihi dan yang kedua disebut dengan khair li khairihi, namun dalam peringkat kualitas, yang pertama lebih tinggi dari yang kedua.xlviii Alasannya memang cukup sederhana yakni bila pada khair li zatihi nilai baiknya bersifat universal dan tidak terikat oleh ruang dan waktu dan bukan karena sesuatu di luar baik itu sendiri, sementara pada khair li khairihi nilai baiknya bersifat temporal, terikat oleh ruang dan waktu dan terikat oleh konsekuensi dari sesuatu itu yang berada diluar baik itu sendiri.

Sedemikian rupa dapat diungkapkan bahwa jika pada khair li zatihi nilai baiknya inheren dalam sesuatu yang dikatakan 'baik' atau bahkan mendahului dari perbuatan baik tersebut, sementara pada khair li khairihi nilai baiknya dalam 
bentuk konsekuensis atau produk dari suatu perbuatan atau tergantung pada tujuan yang terbatas

Model penafsiran hermeneutika al-Qur`an yang diintroduksir Hasan Hanafi yang hanya bertumpu pada nilai etis realitas melalui pengalaman -baik itu empirik maupun rasional-manusia, maka dapat dikatakan berorientasi pada khair li khairihi yakni suatu bentuk aksiologis-etis yang berkarakter human sentris yang sangat terbuka menyusupnya ideologis dan kepentingan yang berkedok humanis

Dalam perspektif etika Islam di kalangan para filsuf Muslim memang kategori 'baik' li khairihi diterima bahkan diperlukan, namun selain sifatnya bersyarat dan sementara, juga terus diupayakan ke arah pencarian etis yang terbaik dengan jalan mendialogkannya pada hal-hal lain di luar dirinya, baik dengan al-Qur`an dan Hadis maupun dengan pengalaman emperisitasrasionalitas yang secara niscaya terus berkembang. Artinya pemahaman terhadap nilai 'baik' pada khair li khairihi bukan lah sesuatu yang final, sehingga segala bentuk kepentingan dan ideologisasi yang memang sulit untuk dinegasikan secara ketat akan dapat disaring dan dieliminisasi. Namun dalam pemikiran Hasan Hanafi yang mana realitas sebagai awal keberpihakan penafsir di dalam tahapan hermeneutika kritis praktisnya yang berakar pada lingkaran hermeneutisnya, yakni being, sein (meng-ada), mitsein (meng-ada dengan yang lain) dan aussein, in-der-welt sein (meng-ada dalam dunia) seperti diungkap di muka, sangat besar peluang masuknya kepentingan subjektivitas dan ideologis temporal.

Kecuali itu sangat memungkinkan pula terputusnya nilai-nilai keilahiyahan dan semakin menyempitkan fungsi teks dalam proses dan capaian penafsiran. Hal ini lebih dikarenakan teks-teks al-Qur`an sebagai preferensi realitas akan terposisikan pada yang profan sementara penafsir dilihat hanya dalam lingkup sosialitasnya yang sempit dan temporal yang terlepas dari spektrum keuniversalitasannya dan keilahiyahannya. Suatu hal yang sangat mereduksi teks-teks al-Qur`an dan manusia ke sosialitasnya yang temporal dan terbatas. Agaknya ini lah yang menjadi kerisauan penulis, atau bentuk kekhawatiran lain seperti yang telah dipaparkan di awal tulisan ini, bila hermeneutika al-Qur'an Hasan Hanafi ini diterapkan secara utuh. Semestinya Hasan Hanafi membuka ruang dialektik-dialogis dalam prapaham penafsir akan realitas dan pada hasil 'produksi makna' yang diklaimnya dalam proses hermeneutika yang ditampilkannya, sehingga tundingan terhadapnya sebagai gerakan pemikiran yang temporal dan sarat dengan ideologis seperti dilontarkan oleh koleganya semisal Abu Zayd dan Ibn Harb seperti diungkap di depan setidaknya dapat dinetralisir dan dieleminir.

\section{Kesimpulan}

Upaya untuk memperbaharui metodologis keilmuwan dalam ilmu-ilmu keislam, khususnya ilmu 'Ulum al-Qur'an diakui sebagai bentuk kepedulian yang teramat tinggi dalam diri Hasan Hanafi, terlebih lagi setelah pengamatanya menunjukkan bahwa model tafsir yang ada saat ini tidak lagi mampu 
menfungsikan pesan-pesan makna teks al-Qur`an bagi pentrasformasian umat ke arah tercerahkan dan berkeadilan.

Namun sayangnya hermeneutika model yang digagasnya sebagai metodologi penafsiran teks-tek al-Qur'an ternyata sangat bersifat realitashumanis sentris. Konsekuensi dari pemikiran yang ditawarkannya seperti ini secara niscaya akan terperangkap ke dalam pereduksian penafsir dan teks ke dalam realitas sosial yang sempit dan temporal

Dari sisi wacana aksiologis-etis produk hermeneutika seperti ini ternyata mengelompok pada khair li khairihi, suatu nilai etis yang berkadar kualitas lebih rendah dari pada khair li zatihi. Oleh karena itu perlu dibuka ruang gerak yang lebih luas lagi pada tahapan 'praksis kritis' hermeneutikanya dalam alur epistemologis yang bernuansakan dialektis-dialogis, baik pada prapaham penafsir maupun 'produksi makna. Dengan upaya seperti ini paling tidak dapat mengeliminasi sifat subjektivitisme dan ideologi atau pereduksian penafsir dan makna teks pada realitas yang sempit dan temporal yang sangat terbuka bagi kepentingan tertentu.

\section{Catatan akhir:}

i Pelebelan ini di antaranya ditandai dengan adanya keininginan yang amat kuat bagi Hasan Hanafi akan lahirnya penafsiran makna dari teks-teks al-Qur`an yang sangat dekat dengan problematika umat seperti ketidakadilan, penindasan dan eksploitasi terhadap umat Islam yang tidak saja dari luar tetapi juga dari dalam umat Islam itu sendiri seperti dari penguasa masyarakat Muslim Lihat di antaranya tulisan tesis yang telah diterbitkan dalam bentuk buku Ilham B. Saenong, Hermenutika Pembebasan Metodologi Tafsir Al-Qur an Menurut Hasan Hanafi, Taraju, Jakarta, 2002.

ii Fazlur Rahman dengan model tafsir double movementnya, Muhammed Arkoen dengan dekonstruksionismenya dan Muhammad Syahrur dengan analitik bahasanya, kesemuanya ini dalam konteks kajian hermeneutika lebih dekat pada teoritical hermeneutitcs, yakni suatu model kajian dalam hermeneutika yang mengandaikan adanya makna objektif di dalam teks. Untuk hal ini umpamanya lihat Amril M, 'Hermeneutika: Sebuah Eksplanasi Pendahuluan dan Refleksi Keniscayaan Bagi Transformasi Ajaran Islam' makalah disampaikan pada kuliah perdana Mata Kuliah Filsafat Islam dan Barat Pascasarjana Prodi PAFI Semester III IAIN STS Jambi tanggal 19 Februari 2003.

iii Upaya memfungsikan nilai-nilai etis al-Qur`an dalam kehidupan sosial keseharian misalnya dapat dilihat Amril M, "Maulud Nabi Muhammad SAW dalam Telaah Strategi Pengembangan Masyarakat Etis-Qur`anik", makalah disampaikan pada acara Peringatan Maulud Nabi Muhammad SAW Provinsi. Jambi tanggal 29 Mei 2002 di Mesjid Agung al-Falah Jambi.

iv Isa J. Boulatta, 'Hasan Hanafi Terlalu Teoritis untuk Dipraktekkan' terjemahan Saiful Muzani dalam Islamika, vol. 1. no. 1, 1996, h. 21.

v Untuk hermeneutika filosofis di antaranya dapat dilihat Amril M, Op. cit, h. 9-13.

vi Baca lebih lanjut umpamanya Loren Bagus, Kamus Filsafat, Pustaka Gramedia Utama, Jakarta, 2000, h. 600-605.

vii Hasan Hanafi, 'Apa Arti Kiri Islam' dalam Kazuo Shimogaki (ed), Kiri Islam, terjemahan M.I Azis dan M.J. Maulana, LKIS, Yogyakarta, 1994, h. 105. Selanjutnya ditulis Kiri....

viiiAdalah Nashr Hamid Abu Zayd, hermuneutis Qur`anik-teoritis dari Universitas Kairo Mesir, yang dituduh murtad, mengatakan bahwa sesungguhnya Hasan Hanafi terlalu memberi porsi yang berlebihan terhadap penafsir dan mengabaikan teks-teks keagamaan sebagai entitas yang memiliki otonomi, sistem hubungan-hubungan intern. Dalam konteks wacananya sendiri.Hasan Hanafi, lanjut Nashr Hamid Abu Zayd, menerapkan eklektisisme terhadap teks-teks tradisional sepanjang mendukung proyek pemikirannya. Pada hal setiap konsep dalam tradisi 
Al-Fikra: Jurnal Ilmiah Keislaman, Vol. 4, No. 1, Januari-Juni 2005

tersebut senantiasa dalam hubungan yang tidak dapat dipisahkan dengan konteksnya sendirisendiri yang boleh jadi kontradiktif dengan penafsiran yang dilakukan olehnya. Tendensi subjektivitas-ideologis yang menggayut pada model penafsiran al-Qur`an Hasan Hanafi juga menjadi sasaran bidik Ali Harb, seorang pemikir kontemporer Mesir, mengatakan secara sinis bahwa Hasan Hanafi tidak menyadari bahwa dirinya mengindap apa yang disebut dengan 'narsisme intelektual' yang mengendap jauh di balik tumpukan analisis dan kemasan konseptual pemikirannya. Sebagai anak zamannya model seperti itu bukan khas milik Hasan Hanafi seorang, tetapi ini semacam efek euforia pembaruan di kalangan intelektual Arab. Mereka termasuk Hasan Hanafi selalu merasa bertangguing jawab terhadap proses pembaharuan di dunia Islam, pada hal sesungguhnya kelompok seperti ini hanya bekerja demi reputasi dan ego masing-masing. Lihat lebih lanjut Nashr Hamid Abu Zayd, Naqd Khitab al-Din, Sina li al-Nasyr, Kairo, 1992, h. 182 dan Ali Harb, Naqd al-Nash, al-Markaz Ats-Tsaqafi al-'Arabi, Beirut, 1995, h. 27-65.

ixHasan Hanafi, Dialog Agama dan Revolusi, terjemahan Tim Pustaka Firdaus, Firdaus, Jakarta, 1991., h. 1. Selanjutnya ditulis Dialog....

$\times$ Lihat lebih lanjut Hasan Hanafi, Islam in the Modern World : Tradition, Revulution and Culture, vol. 2, Anglo-Egyptian Bookshop, 1995, h. 184

xi I $b$ id, h. 187-188.

xii Hasan Hanafi, Dialog...,Op. cit, h. 1-2

xiii $I b$ i $d$, h. 7 .

xiv $I b i d$, h. 1

xv $I b i d$.

xvi Adalah sebuah kelaziman yang ditemukan dalam filsafat fenomenologi kata eiditis didahului oleh reduksi atau visi, sehinga menjadi 'reduksi eiditis' atau visi eiditis' yang maknanya secara simplisit adalah penyaringan fenomena dari eksistensinya dalam kesadaran pada eidos (hakekat) yang ada pada fenomena tersebut. Lihat lebih lanjut umpamanya Walter Biemel, 'Phenomenology' dalam Morteimer J. Adler et all (eds), Encyclopedia Britanica, vol. 14, University of Chicago, Chicago, 1979, h. 212.

xviiHasan Hanafi, Dialog...,Op. cit, h. 16.

xviiiLihat lebih lanjut K. Bertens, Filsafat Barat Abad XX : Inggeris-Jerman, Gramedia , Jakarta,

1983, h, 101.

xixHasan Hanafi, Dialog...,Op. cit, h. 18.

xx I $b$ id, h. 18-20

xxi $I b$ id, h. 21.

xxii $I$ bid. h. 22

xxiii $I b$ id, h 17 dan 22.

xxiv $I b i d$, h 22.

xxv Hasan Hanafi, al-Din wa al-Tsaurah fi al-Mishr1956-1981: al-Yamin wa al-Yasar fi al-Fikr al-

Din, vol.7, Maktabah Madbuli, Kairo, 1989, h.78. Selanjutnya ditulis al-Din.. vol. 7

xxvi Hasan Hanafi, Qadaya....Op. cit, h. 176

xxvii Hasan Hanafi 1988, h. 539

xxviii Hasan Hanafi, Islam in The Modern World: Religion, Ideology, and Development, vol. 1,

Anglo-Egyptian Bookshop, Kairo, 1995, h. 408-4-9. Selanjutnya ditulis Islam vol. 1...

xxix Hasan Hanafi, Qadaya..., Op. cit, h. 177-178.

xxx Hasan Hanafi, Dirasat Falsafiyah, Maktabah Aglo Mishriyah, Kairo, 1988, h. 530. Selanjutny ditulis....Dirasat....

xxxi Hasan Hanfi, Islam vol. 1 ..., Op. cit, h. 418

xxxii $I$ b i d, h. 408-409.

xxxiii Hasan Hanafi, Qadaya... Op. cit, h. 177

xxxiv $I b i \mathrm{~d}, \mathrm{~h} .176$

xxxv $I b i \mathrm{~d}, \mathrm{~h} .179$.

xxxvi Hasan Hanafi, Islam, vol. 2... Op. cit, h. 187.

xxxvii Hasan Hanafi, Islam, vol. 1...Op. cit, h. 416.

xxxviii Hasan Hanafi, Hamum al-Fikr wa al-Wathan: al-Turats al-Ashr wa al-Hadatsah, vol.2, Dar al-Quba', Kairo, 1997, h. 23-30. Selanjutnya ditulis Hamum....

xxxix Hasan Hanafi, Islam... vol.1 Op.cit, h. 417-18 
Al-Fikra: Jurnal Ilmiah Keislaman, Vol. 4, No. 1, Januari-Juni 2005

xl Bagi Hasan Hanafi asbab al-nuzul untuk menunjukkan supremasi realitas, nasikh-mansukh untuk menunjukkan pentahapan dalam penetapan aturan hukum. Juga menunjukkan eksistensi wahyu dalam waktu, perubahannya menurut kesanggupan manusia dan keselarasannya dengan perkembangan kedewasaan individu dan masyarakat dalam sejarah. Lihat Hasan Hanafi, Kiri...Op.Cit, h.103.dan Hasan Hanafi, Dirasat...Op.Cit, h. 71. Mashlahah menunjukkan pula akan prioritas tujuan wahyu sebagai peristiwa dalam sejarah. Lihat Hasan Hanafi, al-Din... vol VII. Op. Cit, h. 72. Relasi ketat antara wahyu dan realitas melalui tiga konsep di atas, menjadikan Hasan Hanafi berkesimpulan bahwa pada hakekatnya hubungan keduanya ini merefleksikan relasi pengetahuan dan tindakan. Wahyu merupakan pembentuk realitas, realitas adalah wahyu pembentuk dalam pikiran. Ini lah keistimewaan al-Qur`an, terletak pada kemampuannya membangun pengetahuan dan kemudian praksisnya dalam kenyataan Lihat lebih lanjut Hasan Hanafi, Humam...Op.cit, h. 46-47..

xli Menurut Gadamer penafsiran selalu merupakan proses sirkular. Kita hanya dapat memahami masa lalu, teks, orang lain dan seterusnya dari susdut pandang dan sisuasi historis kita. Penafsiran selalu merupakan reinterpretasi. Ia adalah meditasi masa lalu dan masa kini atau merupakan semacam the fusion of horizons antara masa lalu dan masa kini. Sekalipu seorang penafsir tidak dapat memulai dengan pikiran kosong dan prasangkanya tidak dapat dinegasikan, namun suatu penafsiran yang benar harus tetap memelihara keterbukaan terhadap teks, membiarkan prasangkanya berubah dan dikoreksi pada saat berkonfrontasi dengan materi tersebut. Lihat lebih lanjut umpamanya Janet Wolff, 'Hermeneutics and Sociology' dalam H. Etzkowits dan Ronald M.Glassman (eds), The Renaiscience of Sociologial Theory, F.E.Peacock Publishers Inc, Ithaca, 1991, h. 189.

xlii Hasan Hanafi, Islam...vol.1 Op.cit, h. 421- 423

xliii $I b$ id, h. $295-308$.

xliv $I$ b i d, h. 297-335

xlv Hasan Hanafi, al-Din ...vol. 7, Op.cit. h. 102-111.

xlvi Hasan Hanafi, Islam vol. 1... Op. cit, h. 417- 418.

xlvii Untuk pengertian lebih lanjut tentang teleologis dan deontologis dalam wacana etika dapat dibaca lebih lanjut umpamanya Nancy Davis (Ann), 'Contemporary Deontology' dalam Peter Singer (ed), A Companion to Ethics, Blackwell, New York, 1992, h. 205-211. Paul W.Taylor, 'Deontological Ethics and Criticisms of Utilitarianism' dalam Paul W. Taylor (ed), Problems of Moral Philosophy, Dickenson Publishing Company Inc,Belmont,California, 1967. h. 212-219. Sedanglkan untuk khair li khairihi dan khair li zatihi umpamanya lihat Amril M. Etika Islam Pemikiran Filsafat Moral Raghib al-Isfahani, Pustaka Pelajar, Yogyakarta, 2002, h. 212

xlviii $I b$ i d, h. 216-218 